\title{
PERLINDUNGAN HUKUM TERHADAP PELAJAR YANG MELAKUKAN TINDAK PIDANA PENYALAHGUNAAN OBAT JENIS PSIKOTROPIKA (Studi Di Polres Purbalingga)
}

Oleh: Nur Fauzan1

\begin{abstract}
Types of Psychotropic drugs abuse at this time to the attention of various circles and continuous discussed and published. Ironically, not only among adults, drug types of psychotropic substances are so well known and it has often been consumed amongst teenagers and minors.

The specification is a descriptive research analytical, data sources that are used in this research is the primary data and secondary data, method of data analysis used is qualitative method.

The CRIMINAL CODE divides all types of criminal act became a big two classes namely the crime contained in book II of the CRIMINAL CODE and the offences contained in Book III of the CRIMINAL CODE. Whereas book I which contains the principles of criminal law is generally applicable to all positive criminal law. The existence of a categorization of the different types of psychotropic drugs, as regulated in the law No. 5 of the year 1997 is merely a psychoactive drug that has the potential to result in a dependency syndrome. While outside the classifications of psychotropic substances above, there are still other psychotropic drugs which have no potential for causing such syndrome, which is subject to the rules and regulations applicable in the field of hard drugs.

Keywords: law protection, student, psychotropic
\end{abstract}

\section{ABSTRAK}

Penyalahgunaan obat-obatan jenis Psikotropika saat ini menjadi perhatian berbagai kalangan dan terus menerus dibicarakan dan dipublikasikan. Ironisnya, tidak hanya dikalangan dewasa saja, obat jenis Psikotropika begitu dikenal dan sudah sering dikonsumsi dikalangan remaja dan anak di bawah umur.

Spesifikasi adalah penelitian deskriptif analitis, sumber data yang digunakan dalam penelitian ini adalah data primer dan data sekunder, metode analisis data yang digunakan adalah metode kualitatif.

KUHP membagi semua jenis tindak pidana menajdi dua golongan besar yaitu golongan kejahatan yang termuat dalam Buku II KUHP dan golongan pelanggaran yang termuat dalam Buku III KUHP. Sedangkan Buku I yang memuat asas-asas hukum pidana pada umumnya berlaku bagi seluruh hukum pidana positif. Adanya penggolongan tentang jenis-jenis psikotropika tersebut, karena yang diatur dalam Undang-Undang No. 5 tahun 1997 hanyalah psikotropika yang mempunyai potensi mengakibatkan sindroma ketergantungan. Sedangkan di luar penggolongan psikotropika di atas, masih terdapat psikotropika lainnya yang tidak mempunyai potensi yang mengakibatkan sindroma seperti itu, yang peraturannya tunduk kepada peraturan perundang-undangan yang berlaku di bidang obat keras.

Kata Kunci: perlindungan hukum, pelajar, psikotropika 


\section{A. Pendahuluan}

Penyalahgunaan obat-obatan jenis Psikotropika saat ini menjadi perhatian berbagai kalangan dan terus menerus dibicarakan dan dipublikasikan. Ironisnya, tidak hanya dikalangan dewasa saja, obat jenis Psikotropika begitu dikenal dan sudah sering dikonsumsi dikalangan remaja dan anak di bawah umur.

Psikotropika merupakan bagian dari narkoba yaitu segolongan obat, yaitu zat yang jika masuk ke dalam tubuh secara berlebihan berpengaruh terutama pada fungsi otak dan dan saraf (sistem saraf pusat) untuk menghasilkan efek menenangkan. Obat ini sering menimbulkan ketergantungan karena bekerja dengan meningkatkan efek dari zat kimia alami tertentu dalam tubuh. Yang mana nantinya akan menimbulkan perubahan dalam kesadaran, pikiran, perasaan, dan perilaku pemakainya.

Psikotropika di satu sisi, merupakan obat atau bahan yang bermanfaat di bidang pengobatan atau pelayanan kesehatan dan pengembangan ilmu pengetahuan, dan di sisi lain, dapat menimbulkan ketergantungan yang sangat merugikan apabila dipergunakan tanpa adanya pengendalian, pengawasan yang ketat dan seksama. Perkembangan penyalahgunan psikotropika dalam kenyataan semakin meningkat, mendorong Pemerintah Indonesia menerbitkan Undang-Undang
Nomor 5 tahun 1997 tentang Psikotropika.

Pada era sekarang ini, banyak sekali pelajar yang sangat mudah mendapatkan obat jenis Psikotropika, baik dari luar ataupun dalam sekolah, dikarenakan karena harganya yang terjangkau juga cara mendapatkannya yang tidak sulit. Hal ini dapat menimbulkan bahwa, tidak menutup kemungkinan akan bertambahnya pula pelajar di wilayah Purbalingga yang melakukan penyalahgunaan obat jenis Psikotropika.

Banyaknya anak pelajar yang mengkonsumsi obat-obatan jenis Psikotropika di wilayah Purbalingga tidaklah sedikit, hal ini memberikan daya tarik kepada penulis untuk melakukan penelitian yang berjudul "Perlindungan Hukum Terhadap Pelajar Yang Melakukan Tindak Pidana Penyalahgunaan Obat Jenis Psikotropika" yang berada di Wilayah Purbalingga.

\section{B. Metode Penelitian}

Penelitian hukum ditinjau dari sudut tujuan penelitian hukum ada dua yaitu penelitian hukum normatif dan penelitian hukum sosiologis atau empiris. ${ }^{2}$ Pendekatan empiris yaitu penelitian yang menggunakan fakta-fakta empiris yang diambil dari perilaku manusia, baik perilaku verbal yang didapat melalui 
1423 | Jurna | I d e a H u k u m

Vol. $5 \mathrm{No} .20 \mathrm{ktober} 2019$

Magister IImu Hukum Universitas Jenderal Soedirman

wawancara maupun perilaku nyata yang dilakukan melalui pengamatan langsung. ${ }^{3}$ Spesifikasi yang digunakan dalam penelitian ini adalah penelitian deskriptif analitis, yaitu penelitian yang bertujuan untuk memperoleh gambaran yang jelas dan sistematis mengenai keadaan atau fakta yang ada terhadap permasalahan yang diteliti dan dipelajari sebagai sesuatu yang utuh. ${ }^{4}$

Sumber data yang digunakan dalam penelitian ini adalah data primer dan data sekunder. ${ }^{5}$ Teknik pengumpulan data dalam penelitian hukum empiris terdapat 3 tekhnik yang dapat digunakan, baik secara sendirisendiri atau terpisah maupun digunakan secara bersama-sama sekaligus. Ketiga tekhnik tersebut adalah wawancara, angket atau kuesioner dan observasi. Dari ketiga tekhnik tersebut masingmasing memiliki kelemahan, karena ketiga tekhnik tersebut tidak menunjukan satu lebih unggul ataupun lebih baik dari yang lainnya. Metode kualitatif adalah suatu tata cara penelitian yang menghasilkandata deskriptif-analisis, yaitu apa yang dinyatakan oleh responden secara tertulis atau lisan, dan juga perilakunya yang nyata, yang teliti, dan dipelajari sebagai sesuatu yang utuh. Dalam penelitian ini metode

3 Ibid., hlm.7

4 Mukti Fajar ND, Dkk, 2010, Dualisme Penelitian Hukum Normatif dan Empiris, Pustaka Pelajar, Yogyakarta, hlm. 192 5 lbid., hlm. 280 analisis data yang digunakan adalah metode kualitatif. ${ }^{6}$

\section{Hasil Penelitian dan Pembahasan}

1. Perlindungan Hukum Terhadap Pelajar

a. Pengertian Perlindungan Hukum

Menurut Satjipto Rahardjo, Perlindungan hukum adalah memberikan pengayoman kepada hak asasi manusia yang dirugikan orang lain dan perlindungan tersebut diberikan kepada masyarakat agar mereka dapat menikmati semua hak-hak yang diberikan oleh hukum atau dengan kata lain perlindungan hukum adalah berbagai upaya hukum yang harus diberikan oleh aparat penegak hukum untuk memberikan rasa aman, baik secara pikiran maupun fisik dari gangguan dan berbagai ancaman dari pihak manapun.7

Menurut Setiono, perlindungan hukum adalah tindakan atau upaya untuk melindungi masyarakat dari perbuatan sewenang-wenang oleh penguasa yang tidak sesuai dengan aturan hukum,

6 Soerjono Soekanto dan Sri Mamuji, 2007, Penelitian Hukum Normatif Suatu Tinjauan Singkat, PT. Raja Grafindo Persada , Jakarta, hlm.13

7 Satjipto Rahardjo. Loc Cit. hlm. 74. 


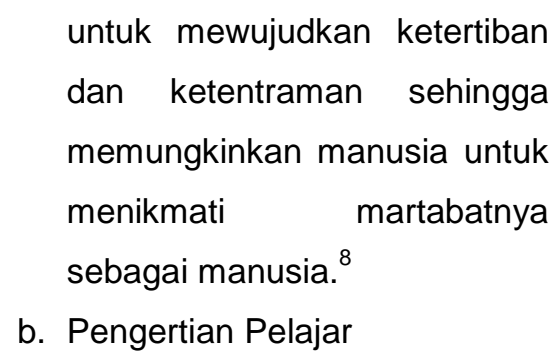

b. Pengertian Pelajar

$$
\begin{aligned}
& \text { Dalam Kamus Besar } \\
& \text { Bahasa Indonesia yang } \\
& \text { mengartikan pelajar sebagai } \\
& \text { orang (anak) yang sedang } \\
& \text { berguru atau bersekolah. } \\
& \text { Pelajar menurut Soekirno } \\
& \text { adalah anak yang belum } \\
& \text { dewasa dan memerlukan } \\
& \text { pertolongan dan bimbingan } \\
& \text { dari pihak lain (orang dewasa) } \\
& \text { agar dapat melaksanakan } \\
& \text { tugasnya sebagai umat Tuhan, } \\
& \text { anggota masyarakat dan } \\
& \text { sebagai individu. }{ }^{9} \\
& \text { Dalam definisi lain, } \\
& \text { Soekirno mendefinisikan: } \\
& \text { Pelajar adalah individu yang } \\
& \text { tercatat sebagai siswa disuatu } \\
& \text { sekolah. Aktif mengikuti } \\
& \text { kegiatan belajar mengajar } \\
& \text { melakukan kewajibannya } \\
& \text { sebagai pejalar dan mengikuti } \\
& \text { peraturan-peraturan yang ada } \\
& \text { di sekolah. } \\
& \text { c. Pengertian Anak } \\
& \text { Merujuk dari Kamus } \\
& \text { Umum bahasa Indonesia }
\end{aligned}
$$

8 Setiono. Rule of Law (Supremasi Hukum). Surakarta. Magister IImu Hukum Program Pascasarjana Universitas Sebelas Maret. 2004. hlm. 3

9 Soekirno, Kamus Besar Bahasa Indonesia, (Balai Pustaka : 1993), hal. 26 mengenai pengertian anak secara etimologis diartikan dengan manusia yang masih kecil ataupun manusia yang belum dewasa. ${ }^{10}$

Dalam hal mengenai pembahasan anak, maka diperlukan suatu perumusan yang dimaksud dengan anak, termasuk batasan umur. Pengertian anak berdasarkan Pasal 1 ayat (1) UndangUndang Republik Indonesia Nomor 35 Tahun 2014 Tentang Perubahan Atas Undang-Undang Republik Indonesia Nomor 23 Tahun 2002 Tentang Perlindungan Anak adalah seseorang yang belum berusia 18 (delapan belas) tahun, termasuk anak yang masih dalam kandungan.Berdasarkan Pasal tersebut, seseorang yang disebut dengan anak adalah seseorang yang belum berusia 18 (delapan belas) tahun dan termasuk juga anak yang masih dalam kandungan ibunya.

d. Perlindungan Hukum Anak

Perlindungan Hukum
Anak adalah suatu usaha
mengadakan kondisi dan
situasi yang memungkinkan

10 W.J.S. Poerwadarminta, Kamus Umum Bahasa Indonesia, (Balai Pustaka : Amirko, 1984), hal. 25 
1425 | Jurna | I d e a H u k u m

Vol. $5 \mathrm{No} .20 \mathrm{ktober} 2019$

Magister IImu Hukum Universitas Jenderal Soedirman

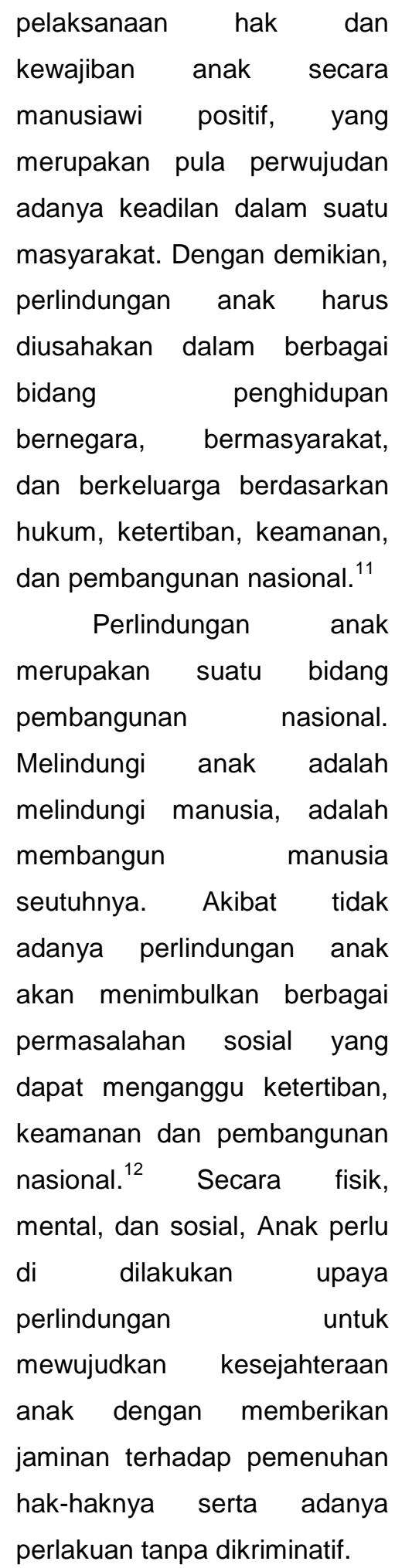

11 Moch Faisal Salam, Op cit hal 2. 12 Arif gosita. Masalah Perlindungan Anak. Jakarta: Akademika Pressindo,1985. Hal :18
Dalam Undang-undang

RI No. 35 Tahun 2014 Tentang Perubahan Atas UU RI No. 23 tahun $2002 \quad$ Tentang Perlindungan Anak juga menyebutkan dalam Pasal 9 ayat (1) dan ayat (1a) yaitu : Pasal 9 ayat (1) berbunyi :

"Setiap Anak berhak memperoleh pendidikan dan pengajaran dalam rangka pengembangan pribadinya dan tingkat kecerdasannya sesuai dengan minat dan bakat".

Dalam Undang-Undang Perlindungan Anak Pasal 20 juga disebutkan bahwa yang berkewajiban dan bertanggung jawab terhadap penyelenggaraan perlindungan anak adalah Negara, pemerintah, masyarakat, keluarga dan orang tua. Jadi perlindungan anak bukanlah tanggung jawab negara atau orang tua saja, melainkan harus diselenggarakan secara bersama-sama oleh negara, pemerintah, masyarakat, keluarga dan orang tua agar pelaksanaan perlindungan anak yang efektif, rasional positif, bertanggung jawab dan bermanfaat dapat tercapai. 


\begin{abstract}
Perlindungan hukum bagi anak-anak merupakan salah satu pendekatan untuk melindungi anak- anak di Indonesia, agar perlindungan anak secara teratur dan tertib dan bertanggung jawab maka perlu peraturan hukum yang selaras dengan perkembangan masyarakat indonesia sesuai denagn pancasila dan undangundang dasar 1945.
\end{abstract}

2. Tindak Pidana Penyalahgunaan Obat Jenis Psikotropika

\section{a. Pengertian Tindak Pidana}

Tindak pidana menurut Bambang Poernomo, yaitu perbuatan yang dilakukan oleh seseorang dengan melakukan suatu kejahatan atau pelanggaran pidana yang merugikan kepentingan orang lain atau merugikan kepentingan umum. Beberapa Sarjana Hukum Pidana di Indonesia menggunakan istilah yang berbeda-beda menyebutkan kata "Pidana", ada beberapa sarjana yang menyebutkan dengan tindak pidana, peristiwa pidana, perbuatan pidana atau delik. ${ }^{13}$

\begin{tabular}{lr}
\multicolumn{2}{c}{ Perbuatan pidana } \\
adalah perbuatan yang \\
dilarang oleh suatu aturan
\end{tabular}

13 Bambang Poernomo. Asas-asas Hukum Pidana. Jakarta. Ghalia Indonesia. 1997. hlm. 86 hukum larangan mana disertai ancaman (sanksi) yang berupa pidana tertentu, bagi barang siapa melanggar larangan tersebut. Dapat juga dikatakan bahwa perbuatan pidana adalah perbuatan yang oleh suatu aturan hukum dilarang dan diancam pidana, asal saja dalam pada itu diingat bahwa larangan diajukan kepada perbuatan, (yaitu suatu keadaan atau kejadian yang ditimbulkan oleh kelakuan orang), sedangkan ancaman pidananya ditujukan kepada orang yang menimbulkannya kejadian itu. ${ }^{14}$

b. Tindak Pidana Psikotropika KUHP membagi semua jenis tindak pidana menajdi dua golongan besar yaitu golongan kejahatan (misdrijven) yang termuat dalam Buku II KUHP dan golongan pelanggaran (overtreading) yang termuat dalam Buku III KUHP. Sedangkan Buku I yang memuat asas-asas hukum pidana pada umumnya berlaku bagi seluruh hukum pidana positif.

Disamping tindak pidana yang tercantum dalam KUHP Jakarta. Rineka Cipta. 2005. hlm. 54 
1427 | Jurna | I d e a H u k u m

Vol. $5 \mathrm{No} .2$ Oktober 2019

Magister II mu Hukum Universitas Jenderal Soedirman

ada beberapa macam tindak pidana di luar KUHP yang bisa disebut sebagai tindak pidana di luar KUHP atau disebut juga sebagai tindak pidana khusus.

Antara KUHP dengan aturan-aturan pidana lain yang ada di luar KUHP itu ada titik pertalian. Titik pertalian itu terletak pada aturan umum buku I KUHP Pasal 103 sebagai berikut:

"Ketentuan-ketentuan dalam Bab I sampai Bab VIII Buku ini juga berlaku bagi perbuatanperbuatan yang oleh ketentuan perUndang-Undangan lain diancam dengan pidana, kecuali jika oleh UndangUndang ditentukan lain"

Jadi ketentuanketentuan dalam Bab I sampai Bab VIII buku I KUHP itu berlaku juga bagi kejahatankejahatan yang ada di luar KUHP, kecuali jika UndangUndang menentukan lain. Artinya Undang-Undang yang bersangkutan itu sendiri menentukan aturan-aturan khusus yang menyimpang dari aturan umum. Undang-Undang No. 5 tahun 1997 tentang Psikotropika merupakan salah satu dari begitu banyak perundangan pidana khusus yang tersebar di luar KUHP.
Menurut Pasal 3 Undang-Undang No. 5 Tahun 1997, tujuan utama pengaturan di bidang psikotropika adalah untuk :

1) Menjamin ketersediaan psikotropika guna kepentingan pelayanan kesehatan dan ilmu pengetahuan;

2) Mencegah terjadinya penyalahgunaan psikotropika;

3) Memberantas peredaran gelap psikotropika.

c. Pengertian Psikotropika

Pengertian psikotropika berdasarkan ketentuan Pasal 1 angka 1 Undang-Undang No. 5 Tahun 1997 adalah zat atau obat, baik alamiah maupun sintesis bukan narkotika, yang berkasiat psikotropika melalui pengaruh selektif pada susunan saraf pusat yang menyebabkan perubahan khas pada aktifitas mental dan perilaku.

Pengertian tersebut menekankan adanya pembatasan ruang lingkup psikotropika yang dipersempit, yaitu zat dan obat yang bukan narkotika, dengan maksud agar tidak berbenturan dengan ruang lingkup narkotika. Karena apabila tidak dibatasi 
demikian, nantinya akan mengalami kesulitan untuk membedakan mana zat atau obat yang tergolong psikotropika dengan mana yang tergolong narkotika.

Dengan memperhatikan tujuan undang-undang, tampak bahwa pada pokoknya menghendaki psikotropika hanya digunakan untuk kepentingan pelayanan kesehatan dan ilmu pengetahuan saja, oleh karena itu penggunaan psikotropika diluar kepentingan tersebut, merupakan pemakaian yang ilegal atau tidak sah.

Jadi pada prinsipnya di dalam pelayanan kesehatan psikotropika digunakan untuk penyembuhan suatu penyakit, sesuai dengan aturan dunia kedokteran yang berlaku. Orang yang sakit diobati dengan obat-obatan yang termasuk psikotropika, supaya menjadi sehat kembali. Kemudian dalam ilmu pengetahuan, penggunaan psikotropika dimaksud untuk kepentingan penelitian dan pengembangan ilmu yang tujuannya untuk kepentingan ilmiah, kedokteran/kesehatan, dan masyarakat.

d. Penggolongan Psikotropika
Undang-Undang

Psikotropika membedakan jenis-jenis psikotropika menjadi 4 (empat) golongan, yaitu :

1) Psikotropika golongan I

2) Psikotropika golongan II

3) Psikotropika golongan III

4) Psikotropika golongan IV

Adanya penggolongan tentang jenis-jenis psikotropika tersebut, karena yang diatur dalam Undang-Undang No. 5 tahun 1997 hanyalah psikotropika yang mempunyai potensi mengakibatkan sindroma ketergantungan. Sedangkan di luar penggolongan psikotropika di atas, masih terdapat psikotropika lainnya yang tidak mempunyai potensi yang mengakibatkan sindroma seperti itu, yang peraturannya tunduk kepada peraturan perundang-undangan yang berlaku di bidang obat keras. Jenis-jenis psikotropika seperti tercantum dalam daftar di atas untuk semua golongan dapat dilakukan perubahan yang ditetapkan oleh Menteri Kesehatan RI dan perubahannya menyesuaikan dengan daftar perubahan psikotropika yang dikeluarkan oleh badan internasional di bidang psikotropika dan dengan memperhatikan kepentingan 
1429 | Ju rna | | d e a H u ku m

Vol. $5 \mathrm{No} .20 \mathrm{ktober} 2019$

Magister IImu Hukum Universitas Jenderal Soedirman

$\begin{aligned} & \text { nasional dalam pelayanan } \\ & \text { kesehatan. } \\ & \text { 3.Bekerjanya Hukum Dalam } \\ & \text { Masyarakat }\end{aligned}$
Ma

Basis bekerjanya hukum adalah masyarakat, maka hukum akan dipengaruhi oleh faktorfaktor atau kekuatan sosial mulai dari tahap pembuatan sampai dengan pemberlakuan. Kekuatan sosial akan berusaha masuk dalam setiap proses legislasi secara efektif dan efesien. Peraturan dikeluarkan diharapkan sesuai dengan keinginan, tetapi efek dari perturan tersebut tergantung dari kekuatan sosial seperti budaya hukumnya baik, maka hukum akan bekerja dengan baik pula, tetapi sebaliknya apabila kekuatannya berkurang atau tidak ada maka hukum tidak akan bisa berjalan. Karena masyarakat sebagai basis bekerjanya hukum. Lawrence M.Friedman dalam bukunya menyebutkan bahwa sistem hukum terdiri atas perangkat struktur hukum (berupa lembaga hukum), substansi hukum (peraturan perundang-undangan) dan kultur hukum atau budaya hukum. Ketiga komponen ini mendukung berjalannya sistem hukum di suatu negara. Secara realitas sosial, keberadaan sistem hukum yang terdapat dalam

$$
\begin{array}{lr}
\text { masyarakat mengalami } & \text { sebagai }
\end{array}
$$$$
\text { akibat pengaruh, apa yang }
$$
disebut dengan modernisasi atau globalisasi baik itu secara evolusi maupun revolusi.

Penelitian ini dilakukan di Kepolisian Resort (Polres) Purbalingga Khusunya yaitu di Satuan Reserse Narkoba. Polres Purbalingga terletak di Jalan Mayjend Sungkono No. 1 Kecamatan Kalimanah Kab. Purbalingga. Kabupaten Purbalingga sendiri berada di bagian Timur kabupaten Banyumas, yang memiliki aksesbilitas baik dan mudah dijangkau.

Sejalan dengan di berlakukannya Undang-Undang Nomor 11 Tahun 2012 Tentang Sistem Peradilan Pidana Anak, telah di pertegas bahwa penyidikan terhadap perkara anak nakal dilakukan oleh penyidik POLRI dengan dasar hukum Pasal 26 ayat 1 yang menyebutkan bahwa :“ penyidikan terhadap perkara anak dilakukan oleh penyidik yang ditetapkan berdasarkan Surat Keputusan Kepala Kepolisian RI atau pejabat lain yang ditunjuk oleh Kapolri".

Menurut penulis, penyidik dalam menangani proses penyidikan terhadap perkara anak nakal seperti pelajar sebagai pelaku 
penyalahgunaan Psikotropika harus mengambil tindakan hati-hati. Dimana dalam memeriksa tersangka harus dalam suasana kekeluargaan. Dengan kata lain dalam pemeriksaannya tidak memakan waktu lama, dengan menggunakan bahasa yang bisa dimengerti oleh anak dan bersikap ramah/sopan serta tidak membuat takut si anak sehingga anak dapat memberikan keterangan yang sejelas-jelasnya. Dalam melakukan penyidikan, penyidik wajib meminta pertimbangan dari Pembimbing Kemasyarakatan. 15

Dari data penanganan perkara Tindak Pidana Penyalahgunaan obat jenis psikotropika yang dilakukan oleh pelajar dari tahun 2014-2015 yang ditangani di Satuan Reserse Narkoba Polres Purbalingga, dapat dibuat data yaitu sebagai berikut :

Tabel 4.5 Penanganan perkara Tindak Pidana Penyalahgunaan obat jenis psikotropika yang dilakukan oleh pelajar dari tahun 2014-2015 yang ditangani di Satuan Reserse Narkoba Polres Purbalingga

\begin{tabular}{|c|c|c|c|}
\hline No & Tahun & $\begin{array}{c}\text { Jumlah } \\
\text { Tersangka } \\
\text { Pelajar }\end{array}$ & $\begin{array}{c}\text { Jumlah } \\
\text { Laporan } \\
\text { Polisi }\end{array}$ \\
\hline 1. & 2014 & 4 & 4 \\
\hline 2. & 2015 & 2 & 1 \\
\hline 3. & 2016 & 3 & 2 \\
\hline 4. & 2017 & 7 & 4 \\
\hline
\end{tabular}

Sumber: Data Penanganan kasus penyalahgunaan obat jenis psikotropika yang dilakukan oleh pelajar, Min

15 Undang-Undang No. 3 Tahun 1997 Tentang Pengadilan Anak, Pasal 42 ayat (2).
Resnarkoba Polres Purbalingga, 20142017

Menindak lanjuti dari data tersebut di atas, dalam hal ini penulis mengambil salah satu contoh kasus tindak pidana penyalahgunaan obat jenis psikotropika yang dilakukan oleh pelajar pada tahun 2017. Penulis melakukan penelitian terhadap kasus penyalahgunaan obat jenis Psikotropika di Satuan Reserse Narkoba Polres Purbalingga pada tahun 2017 yang dilakukan oleh pelajar dengan data sebagai berikut :

Tabel 4.6 Salah satu contoh kasus tindak pidana penyalahgunaan obat jenis psikotropika yang dilakukan oleh pelajar pada tahun 2017

\begin{tabular}{|c|c|c|c|c|c|}
\hline No & Nama & $\underset{r}{U m u}$ & $\begin{array}{c}\text { Agam } \\
\text { a }\end{array}$ & $\begin{array}{c}\text { Pekerj } \\
\text { aan }\end{array}$ & Alamat \\
\hline 1. & $\begin{array}{l}\text { Muha } \\
\text { mmad } \\
\text { Rifqi } \\
\text { Nugro } \\
\text { ho Als. } \\
\text { Rifqi } \\
\text { Als. } \\
\text { Kiki } \\
\text { Als. } \\
\text { Kindul } \\
\text { Bin } \\
\text { Imam } \\
\text { Nugro } \\
\text { ho }\end{array}$ & $\begin{array}{l}16 \\
\text { Th } \\
10 \\
B I\end{array}$ & Islam & $\begin{array}{l}\text { Pelaja } \\
r\end{array}$ & $\begin{array}{l}\text { Desa } \\
\text { Banding } \\
\text { an RT } 2 \\
\text { Rw } 1 \\
\text { Kecamat } \\
\text { an } \\
\text { Kejobon } \\
\text { g Kab. } \\
\text { Purbalin } \\
\text { gga }\end{array}$ \\
\hline 2. & $\begin{array}{l}\text { Lutfi } \\
\text { Aditia } \\
\text { Perda } \\
\text { na Als. } \\
\text { Lutfi } \\
\text { Bin } \\
\text { Muha } \\
\text { mmad } \\
\text { Fadli }\end{array}$ & $\begin{array}{l}16 \\
\text { Th } \\
10 \\
B I\end{array}$ & Islam & $\begin{array}{l}\text { Pelaja } \\
r\end{array}$ & $\begin{array}{l}\text { Desa } \\
\text { Lamuk } \\
\text { RT } 2 \text { Rw } \\
1 \\
\text { Kecamat } \\
\text { an } \\
\text { Kejobon } \\
\text { g Kab. } \\
\text { Purbalin } \\
\text { gga }\end{array}$ \\
\hline
\end{tabular}

Sumber : Data identitas pribadi kasus tindak pidana penyalahgunaan obat jenis psikotropika yang dilakukan oleh pelajar, Min Resnarkoba Polres Purbalingga, 2017

Dari data Pelaku penyalahgunaan Obat jenis Psikotropika tersebut di atas, dapat dijabarkan serangkaian 
1431 | Jurna | I d e a H u ku m

Vol. $5 \mathrm{No} .2$ Oktober 2019

Magister IImu Hukum Universitas Jenderal Soedirman

penanganan Tindak pidana penyalahgunaan obat jenis psikotropika dari awal penangkapan sampai dengan Proses ahir. Apakah dalam hal ini perlindungan terhadap anak pelaku kejahatan penyalahgunaan obat-obatan jenis psikotropika sudah mendapatkan perlindungan hukum ataukah belum sebagaimana disebutkan dalam UU RI No. 35 tahun 2014 tentang perubahan atas UU RI No. 23 tahun 2002 tentang Perlindungan Anak.

Apabila penyidik melakukan penangkapan terhadap pelajar maka penyidik harus membeitahukan orang tua atau wali anak segera keberadaan anak saat menjalani proses hukum. Apabila orang tua atau walinya tidak dapat diketemukan, polisi memberitahukannya kepada Badan Pemasyarakatan (BAPAS) atau dinas sosial. Bappas/dinas sosial mencari tahu darimana asal usul anak tersebut, dengan mendatangi orang tua/wali dari anak tersebut. Setelah mengetahui dari mana asal-usul anak tersebut, selanjutnya Bapas/Dinas Sosial memberitahukan kepada pihak penyidik. Bapas juga bisa memberikan bantuan dalam upaya perlindungan terhadap kepentingannya. Bantuan terhadap anak dapat diberikan oleh lembaga Departemen Sosial, yayasan atau lembaga perlindungan anak dan

lemabaga swadaya masyarakat yang peduli anak. $16^{19}$

Dalam pemeriksaan bappas wajib mendampingi anak dengan tujuan membantu kelancaran wawancara dan memberikan perlindungan terhadap anak. Apabila anak itu tidak ada yang mendampingi pada saat diperiksa maka Bapas yang mendampingi anak tersebut

Menurut AKP Senentyo, SH selaku Kasat Resnarkoba di Satuan Res Narkoba Polres Purbalingga, mengatakan bahwa polisi harus mengambil tindakan hati-hati terhadap anak sebagai pelaku tindak pidana. Artinya bahwa kasus yang dilakukan oleh anak masih tergolong ringan, begitu setelah anak tersebut diperiksa dan ditanyai, barulah diberikan pengertian anak tersebut tidak ditahan. 17

Dalam hal ini, penulis juga melakukan wawancara terhadap beberapa Responden untuk mengetahui apakah Pelajar yang melakukan Tindak Pidana penyalahgunaan Obat jenis Psikotropika sudah mendapatkan perlindungan Hukum sebagaimana disebutkan dalam UU RI No. 35 tahun 2014 tentang perubahan atas UU RI No. 23 tahun 2002 tentang Perlindungan Anak ataukah belum.

16 Hasil wawancara dengan penyidik pembantu yaitu Brigadir Alvian, SH di satuan Res Narkoba Polres Purbalingga pada tanggal 7 Mei 2018.

17 Hasil wawancara dengan Kasat Resnarkoba yaitu AKP Senentyo, SH di satuan Res Narkoba Polres Purbalingga pada tanggal 7 Mei 2018. 
Penelitian ini memberikan contoh tersangka pelajar yang melakukan penyalahgunaan obat jenis Psikotropika, yang mana disebutkan bahwa pelajar tersebut melakukan tindak pidana yang disebutkan dalam UU Psikotropika yaitu Pasal 62 UU RI No. 5 Tahun 1997 tentang Psikotropika.

Pasal 62 UU RI No. 5 tahun 1997 berbunyi :

"Barangsiapa secara tanpa hak, memiliki, menyimpan dan/atau membawa psikotropika dipidana dengan pidana penjara paling lama 5 (lima) tahun dan pidana denda paling banyak Rp. 100.000.000,00 (seratus juta rupiah)".

Sesuai dengan pelanggaran yang dilakukan oleh Pelajar yang bernama Muhammad Rifqi Nugroho Als. Rifqi Als. Kiki Als. Kindul Bin Imam Nugroho dan Lutfi Aditia Perdana Als. Lutfi Bin Muhammad Fadli, maka dalam hal ini cara penanganannya harus menggunakan UU RI No. 35 Tahun 2014 Tentang Perubahan Atas UU RI No. 23 tahun 2002 Tentang Perlindungan Anak dan UU No. 11 Tahun 2012 Tentang Sistem Peradilan Pidana Anak.

Selain itu, peneliti juga mendapatkan hasil penelitian yang yang mana terdapat aturan-aturan sekolah untuk ketertiban terhadap siswasiswanya. Aturan-aturan tersebut di tulis dalam satu buku yang mana isinya terdapat hal-hal apa saja yang dilarang oleh pihak sekolah terhadap siswasiswanya. Aturan-aturan tersebut dituangkan dalam sebuah Pasal yang mana apabila ada salah satu Pasal yang dilanggar oleh pelajar SMK Muhammadiyah 3 Purbalingga, maka pelajar tersebut akan mendapat sanksi sesuai dengan Pasal yang dilanggar. Dibawah ini beberapa aturan yang tidak boleh dilakukan oleh para pelajar SMK Muhammadiyah 3 Purbalingga. Baik di lingkungan sekolah ataupun saat di luar lingkungan sekolah.

1. Menganalisis Perlindungan hukum terhadap pelajar yang melakukan tindak pidana penyalahgunaan obat jenis psikotropika di Polres Purbalingga sudah diberikan atau belum sesuai dengan UU RI Nomor 35 Tahun 2014 Tentang Perubahan Atas Undang-Undang Republik Indonesia Nomor 23 Tahun 2002 Tentang Perlindungan Anak

Anak yang melakukan
tindak pidana umumnya
dikeluarkan dari sekolah, padahal belum ada keputusan tetap yang mengikat, apakah anak tersebut bersalah atau tidak, sehingga menyalahi prinsip praduga tak bersalah dan tentunya menghilangkan hak anak atas pendidikan. Harus diingat, pemenjaran hanya menghilangkan hak bergerak seseorang, sementara hak-hak 
1433 | Jurna | I d e a H u k u m

Vol. $5 \mathrm{No} .20 \mathrm{ktober} 2019$

Magister II mu Hukum Universitas Jenderal Soedirman

lainnya tetap wajib didapatkan. Jika seorang anak dipidana penjara, maka seluruh hakhaknya yang lain wajib diberikan, misalnya hak atas pendidikan, hak untuk terbebas dari tindak kekerasan dan sebagainya.

Berdasarkan hasi
penelitian diatas maka dapa
dianalisa bahwa anak merupakan
aset Negara yang sangat penting
dan perlu untuk diberikan
perlindungan secara optimal
secara yuridis pemerintah telah
membuat suatu Peraturan
Perundang undangan yang mengatur secara khusus tentang bentuk dan cara perlindungan anak yang berkonflik dengan hukum setidaknya merupakan komitmen pemerintah untuk melindungi generasi penerus bangsa, tetapi ada beberapa poin penting yang terkandung di dalam Pasal 64 undang-undang perlindungan anak yang tidak terpenuhi oleh penegak hukum kita didalam proses perlindungan khusus bagi anak yang berhadapan dengan hukum, yaitu setelah anak tersebut melakukan pelanggaran hukum, sudah otomatis anak tersebut langsung dikeluarkan dari sekolah tanpa mempertimbangkan UU No. 35 tahun 2014 Tentang Perubahan Atas UU No. 23 tahun 2002
Tentang Perlindungan Anak, hal ini dapat dilihat dari hasil wawancara penulis dengan beberapa responden.

Berdasarkan hasil wawancara dengan beberapa responden, keputusan yang diambil oleh pihak sekolah sangatlah bertentangan dengan Pasal 9 ayat 1 UU No. 35 tahun 2014 Tentang Perubahan atas UU RI No. 23 tahun 20002 Tentang Perlindungan Anak yaitu kedua anak tersebut dikeluarkan dari sekolah.

Pasal 9 ayat 1

"Setiap Anak berhak memperoleh pendidikan dan pengajaran dalam rangka pengembangan pribadinya dan tingkat kecerdasannya sesuai dengan minat dan bakat".

Dalam hal ini pihak sekolah lebih mengedepankan aturan sekolah dari pada UU RI No. 35 tahun 2014, sehingga hak anak yang disebutkan dalam Pasal 9 ayat (1) belumlah diberikan. Dalam hal ini aturan sekolah yang ditegakan belumlah sejalan dengan UU No. 35 tahun 2014. Berikut adalah hal yang perlu dipahami antara aturan sekolah SMK Muhammadiyah 3 Purbalingga dengan UU No. 35 tahun 2014 yang belumlah sejalan. 
Dalam Penelitian ini menemukan bahwa pelajar yang melakukan tindak pidana penyalahgunaan obat jenis Psikotropika di Polres Purbalingga di keluarkan dari sekolah. Ini sesuai dengan peraturan sekolah yang telah ditentukan oleh SMK Muhammadiyah 3 Purbalingga. Tetapi dalam hal Perlindungan hukum terhadap pelajar yang melakukan penyalahgunaan obat jenis Psikotropika belumlah diberikan sepenuhnya. Dan hal ini tidak sejalan dengan Pasal 9 ayat (1) UU RI No. 35 tahun 2014 yang menyatakan bahwa Setiap Anak berhak memperoleh pendidikan dan pengajaran dalam rangka pengembangan pribadinya dan tingkat kecerdasannya sesuai dengan minat dan bakat. Dalam hal ini seharusnya anak yang melakukan penyalahgunaan obat jenis psikotropika harus tetap dilindungi dalam hal hukum. Dan harus tetap mendapatkan hakhaknya sebagaimana disebutkan dalam Pasal 9 UU RI No. 35 tahun 2014 tentang hak mendapatkan Pendidikan.

Dengan adanya kedua aturan tersebut yaitu aturan dari pihak sekolah SMK Muhammadiyah 3 Purbalingga dan UU RI No. 35 tahun 2014, maka dari pihak sekolah lebih mengutamakan aturan sekolah itu sendiri dari pada UU No. 35 tahun 2014. Ini dapat dibuktikannya bahwa setelah pelajar SMK Muhammadiyah 3 Purbalingga yang melakukan penyalahgunaan obat jenis psikotropika, mereka langsung dikeluarkan dari sekolah. Ini menandakan bahwa aturan sekolah lebih dikedepankan oleh pihak sekolah dari pada UU RI No. 35 tahun 2014.

Dalam hal ini berarti dari pihak sekolah SMK Muhammadiyah 3 Purbalingga belumlah memberikan perlindungan hukum terhadap pelajar tersebut. Sedangkan menurut aturan hukum yang benar menyebutkan bahwa UU RI No. 35 tahun 2014 merupakan aturan hukum yang berada di atas aturan yang dibuat oleh SMK Muhammadiyah 3 Purbalingga. Tetapi pihak sekolah malah lebih melaksanakan aturan yang dibuatnya yaitu aturan sekolah dari pada UU RI No. 35 tahun 2014. Ini berarti menandakan bahwa aturan sekolah yang dibuat oleh SMK Muhammadiyah 3 Purbalingga belumlah sejalan dengan UU RI No. 35 tahun 2014.

2. Hambatan dalam pelaksanaan perlindungan hukum terhadap pelajar yang melakukan tindak 
1435 | Jurna | I d e a H u k u m

Vol. $5 \mathrm{No} .20 \mathrm{ktober} 2019$

Magister IImu Hukum Universitas Jenderal Soedirman

pidana penyalahgunaan obat jenis psikotropika di Polres Purbalingga

Hambatan yang dihadapi dalam memberikan perlindungan hukum terhadap pelajar yang melakukan penyalahgunaan obat jenis psikotropika di Wilayah Purbalingga yaitu bahwa di dalam sekolah itu sendiri terdapat sebuah aturan yang berlaku. Berarti pelajar tersebut sudah dengan otomatis akan dikeluarkan dari sekolah tanpa melihat UU RI No. 35 tahun 2014 Tentang Perubahan atas UU RI No. 23 tahun $20002 \quad$ Tentang Perlindungan Anak yang mana dalam isinya melindungi hak-hak anak itu sendiri. Karena disamping itu, alasan pihak sekolah mengeluarkan anak tersebut dengan alasan pelajar yang melakukan penyalahgunaan obat jenis psikotropika telah mencemarkan nama baik sekolah SMK Muhammadiyah 3 Purbalingga.

Dalam hal ini peneliti akan membahas hambatan yang di alami untuk melakukan perlindungan hukum terhadap pelajar yang melakukan penyalahgunaan obat jenis Psikotropika di Polres Purbalingga jika di hadapkan dengan teori Lawrence M. Friedman yang dalam bukunya menyebutkan bahwa sistem hukum terdiri atas :

a.Perangkat struktur hukum (berupa lembaga hukum),

b.Substansi hukum (peraturan perundang-undangan),

c.Kultur hukum atau budaya hukum.

Ketiga komponen ini mendukung berjalannya sistem hukum di suatu negara. Diharapkan ketiga elemen tersebut harus berfungsi optimal. Tapi pada kenyataannya dalam penelitian ini Perangkat struktur hukum (berupa lembaga hukum), Substansi hukum (peraturan perundang-undangan) dan Kultur hukum atau budaya hukum belumlah dijalankan sepenuhnya. Masih adanya salah satu yang belum di jalankan sehingga sistem hukum belumlah berjalan dengan maksimal. Sehingga dalam hal ini perlindungan hukum terhadap pelajar yang melakukan penyalahgunaan obat jenis Psikotropika di Polres Purbalingga belumlah diberikan dengan sepenuhnya.

Dalam hal ini, Struktur hukum itu sendiri menyangkut aparat penegak hukum, substansi hukum meliputi perangkat perundang-undangan dan budaya hukum merupakan hukum yang hidup (living law) yang dianut 
dalam suatu masyarakat. Dengan melihat pengertian dari teori Lawrence M. Friedman kita dapat menarik kesimpulan bahwasanya ketiga unsur hukum itu harus berjalan bersama agar hukum yang di buat untuk menegakan keadilan itu dapat berjalan efektif, dan keadilan yang di rasakan oleh masyarakat yang di atur oleh hukum itu sendiri. Tapi pada kenyatannya dalam penelitian ini ketiga unsur hukum itu sendiri tidaklah dijalankan semuanya sehingga keadilan belumlah ditegakan dengan bukti bahwa perlindungan hukum terhadap pelajar yang melakukan penyalahgunaan obat jenis psikotropika di Polres Purbalingga belumlah diberikan sepenuhnya.

Berikut ini penulis melakukan pembahasan mengenai kendala-kendala yang dihadapi dalam melakukan perlindungan hukum terhadap pelajar yang melakukan penyalahgunaan obat jenis Psikotropika di Polres Purbalingga berdasarkan teori yang dikemukakan oleh Lawrence M.Friedman.

a. Dilihat dari Sudut pandang Perangkat struktur hukum (berupa lembaga hukum) Struktur Hukum/Pranata Hukum dalam teori Lawrence
Meir Friedman, hal ini disebut sebagai sistem Struktural yang menentukan bisa atau tidaknya hukum itu dilaksanakan dengan baik. Struktur hukum berdasarkan UU No. 8 Tahun 1981 meliputi mulai dari Kepolisian, Kejaksaan, Pengadilan dan Badan Pelaksana Pidana (Lapas). Kewenangan lembaga penegak hukum dijamin oleh undang-undang. Sehingga dalam melaksanakan tugas dan tanggung jawabnya terlepas dari pengaruh kekuasaan pemerintah dan pengaruh-pengaruh lain. Hukum tidak dapat berjalan atau tegak bila tidak ada aparat penegak hukum yang kredibilitas, kompeten dan independen. Seberapa bagusnya suatu peraturan perundang-undangan bila tidak didukung dengan aparat penegak hukum yang baik maka keadilan hanya anganangan. Lemahnya mentalitas aparat penegak hukum mengakibatkan penegakkan hukum tidak berjalan sebagaimana mestinya.

Masalah yang
ditimbulkan dari struktur
hukum untuk penelitian ini
yaitu Aparat penegak hukum


1437 | Jurna | I d e a H u k u m

Vol. $5 \mathrm{No} .2$ Oktober 2019

Magister II mu Hukum Universitas Jenderal Soedirman

khususnya kepolisian belum sepenuhnya memberikan perlindungan hukum terhadap pelajar yang melakukan penyalahgunaan obat jenis psikotropika di Polres Purbalingga. Pada saat pelajar yang melakukan penyalahgunaan obat jenis Psikotropika di Polres Purbalingga, dari pihak sekolah segera mengambil tindakan pemberian sanksi tegas terhadap pelajar tersebut yaitu dikembalikannya pelajar tersebut kepada orang tuanya atau dikeluarkannya pelajar tersebut dari sekolah. Sedangkan dalam hal ini menurut Pasal 9 ayat (1) UU RI No. 35 tahun 2014 menyebutkan bahwa Setiap Anak berhak memperoleh pendidikan dan pengajaran dalam rangka pengembangan pribadinya dan tingkat kecerdasannya sesuai dengan minat dan bakat. Dalam hal ini keputusan yang diambil oleh pihak sekolah SMK Muhammadiyah 3 Purbalingga mendasarkan pada peraturan sekolah yang telah dibuat. Setelah adanya keputusan dari pihak Sekolah SMK Muhammadiyah 3 Purbalingga yang menyatakan pelajar tersebut dikembalikan kepada orang tua / di keluarkan, pihak dari keluarga / orang tua pelajar yang melakukan penyalahgunaan obat jenis psikotropika di Polres Purbalingga tidak bisa berbuat apa-apa. Mau ataupun tidak mau pihak keluarga menerima keputusan dari pihak sekolah. Sedangkan dalam hal ini, aparat penegak hukum khususnya kepolisian tidak bisa melakukan hal yang bisa melindungi hak-hak pelajar / anak yang sedang berhadapan dengan hukum. Walaupun upaya yang telah dilakukan oleh kepolisian tentang perlindungan hukum terhadap pelajar yang melakukan penyalahgunaan obat jenis Psikotropika di Polres Purbalingga yaitu memberikan penjelasan kepada pihak sekolah SMK Muhammadiyah 3 Purbalingga bahwa pelajar tersebut harus tetap dilindungi sebagai mana disebutkan dalam Pasal 9 ayat (1) UU RI No. 35 tahun 2014 yaitu Setiap Anak berhak memperoleh pendidikan dan pengajaran dalam rangka pengembangan pribadinya dan tingkat kecerdasannya sesuai dengan minat dan bakat. Tetapi dari 


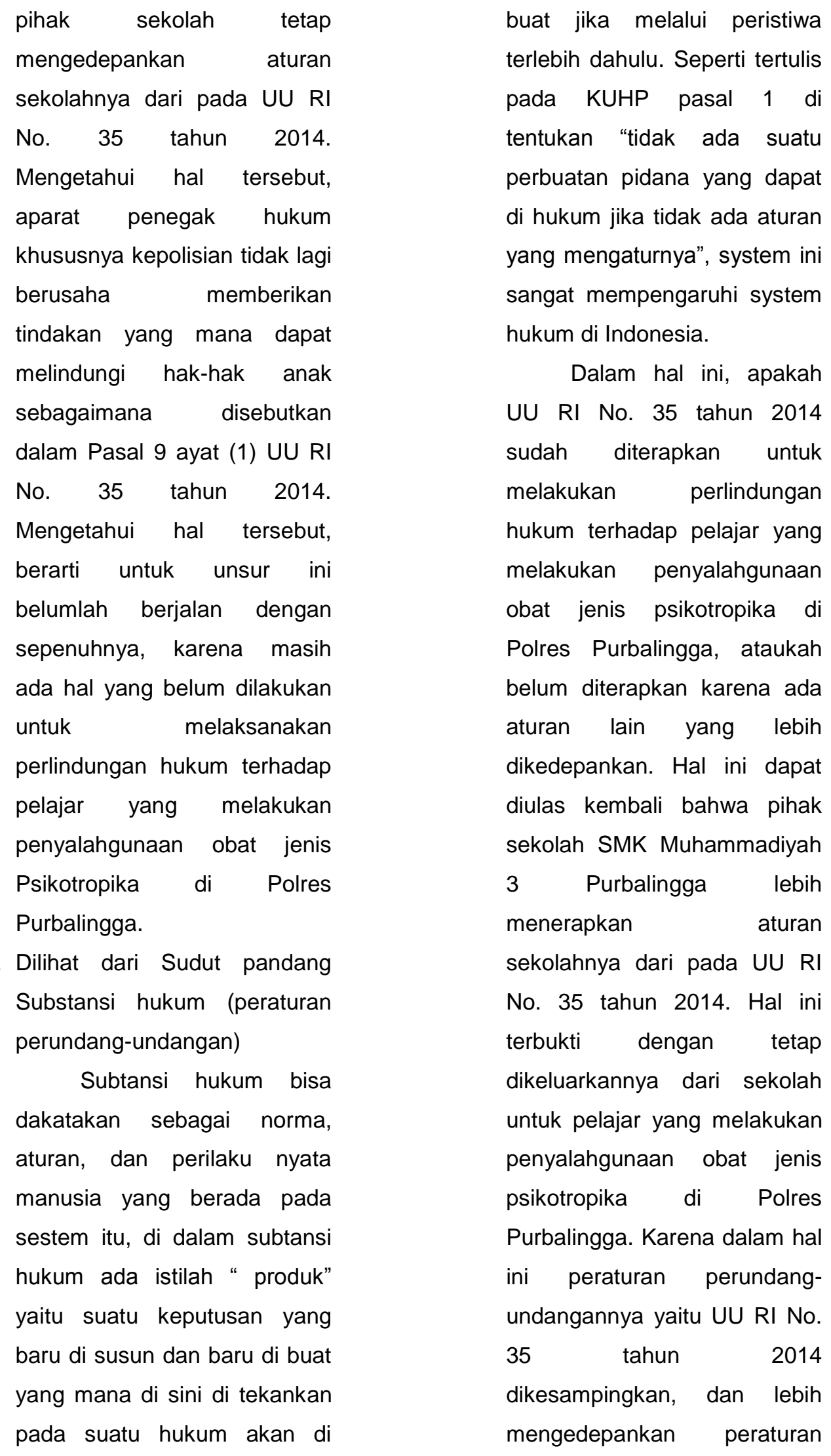


1439 | Jurna | I d e a H u k u m

Vol. $5 \mathrm{No} .20 \mathrm{ktober} 2019$

Magister II mu Hukum Universitas Jenderal Soedirman

yang ada dibawahnya yaitu peraturan yang dibuat dari pihak sekolah SMK Muhammadiyah 3 Purbalingga, maka Dilihat dari Sudut pandang Substansi hukum (peraturan perundangundangan) belumlah dijalankan atau dilaksanakan. Ini akan menjadikan sebuah kendala terhadap pemberian perlindungan hukum terhadap pelajar yang melakukan penyalahgunaan obat jenis psikotropika di Polres Purbalingga. Dalam hal ini, berarti perintah Undangundang belumlah dilaksanakan dengan tegas demi kepentingan bagi pelajar yang melakukan penyalahgunaan obat jenis psikotropika di Polres Purbalingga.

c. Dilihat dari sudut pandang Kultur hukum atau budaya hukum

Budaya hukum ini pun dimaknai sebagai suasana pikiran sosial dan kekuatan sosial yang menentukan bagaimana hukum digunakan, dihindari, atau disalahgunakan. Demikian juga kesenangan atau ketidak senangan untuk berperkara adalah bagian dari budaya hukum. Oleh karena itu, apa yang disebut dengan budaya hukum itu tidak lain dari keseluruhan faktor yang menentukan bagaimana sistem hukum memperoleh tempatnya yang logis dalam kerangka budaya milik masyarakat umum. Maka secara singkat dapat dikatakan bahwa yang disebut budaya hukum adalah keseluruhan sikap dari warga masyarakat dan sistem nilai yang ada dalam masyarakat yang akan menentukan bagaimana seharusnya hukum itu berlaku dalam masyarakat yang bersangkutan.

Dalam hal ini apabila dikaitkan dengan dikeluarkkannya pelajar dari sekolah yang mana pelajar tersebut melakukan penyalahgunaan obat jenis psikotropika di Polres Purbalingga, ini didasarkan atas aturan sekolah. Karena dengan pelajar tersebut melakukan penyalahgunaan obat jenis Psikotropika di Polres Purbalingga, berarti sudah dengan otomatis pelajar tersebut sudah mencemari nama baik sekolah, karena masyarakat beranggapan bahwa ada pelajar dari SMK Muhammadiyah 3 Purbalingga 
yang

melakukan

penyalahgunaan obat jenis

Psikotropika. Selain itu, pengetahuan masyarakat / orang tua dari pelajar tersebut terhadap UU RI No. 35 tahun 2014 belumlah terlalu paham. Karena setelah pelajar tersebut dikeluarkan dari sekolah, pihak orang tua / wali tidak bisa berbuat apa-apa ataupun mengadukan kepada aparat penegak hukum.

Karena pemberian keputusan dalam sekolah tersebut lebih mengedepankan aturan yang dibuat oleh pihak sekolah itu sendiri dari pada peraturan perundangundangan yaitu UU RI No. 35 tahun 2014. Ini tidaklah sesuai dengan teori yang dikemukakan oleh Lawrence M.Friedman. Dalam hal ini, berarti masyarakat belumlah memahami aturan mana yg perlu dikedepankan antara UU RI No. 35 tahun 2014 ataukah aturan yang dibuat oleh pihak sekolah. Begitu juga dengan pihak sekolah, belumlah adanya kesadaran hukum yang mana harus lebih mengedepankan UU RI No. 35 tahun 2014 dari pada peraturan sekolah itu sendiri. Hal ini menjadikan kendala yang dihadapi untuk melakukan perlindungan hukum terhadap pelajar yang melakukan penyalahgunaan obat jenis Psikotropika di Polres Purbalingga.

Hal ini dapat dilihat bahwa dalam melaksanakan perlindungan hukum terhadap pelajar yang melakukan penyalahgunaan obat jenis psikotropika di Polres Purbalingga mengalami banyak kendala, ini dapat dilihat dari ketiga unsur tersebut yang merupakan teori dari Lawrence M.Friedman. Apabila salah satu dari ketiga unsur tersebut belum dijalankan, maka penegakan hukum tidak akan berjalan dengan maksimal, apalagi kalu ketiga unsur tersebut belumlah dilaksanakan.

\section{Simpulan}

Berdasarkan pembahasan keseluruhan materi yang diuraikan mengenai Perlindungan Hukum terhadap Pelajar yang melakukan penyalahgunaan obat jenis Psikotropika di Polres Purbalingga dari awal hingga ahir, dapat diperoleh kesimpulan sebagai berikut:

1. Perlindungan hukum terhadap pelajar yang menyalahgunakan obat jenis Psikotropika di Polres 
1441 | Jurna | I d e a H u k u m

Vol. $5 \mathrm{No} .20 \mathrm{ktober} 2019$

Magister IImu Hukum Universitas Jenderal Soedirman

Purbalingga sesuai dengan UU RI No. 35 tahun 2014 belumlah diberikan sepenuhnya, khususnya pada Pasal 9 ayat 1 yang menjelaskan bahwa setiap anak berhak mendapatkan pendidikan. Tetapi pada kenyataannya pelajar yang melakukan penyalahgunaan obat jenis psikotropika di Polres Purbalingga masih tetap dikeluarkkan dari sekolah. Hal ini tidak sesuai dengan UU RI No. 35 tahun 2014.

2. Dalam melaksanakan perlindungan hukum terhadap Pelajar yang melakukan penyalahgunaan obat jenis Psikotropika di Polres Purbalingga masih mendapati kendala, yaitu pelajar tersebut tetap dikeluarkan dari pihak sekolah, sehingga anak tersebut tidak medapatkan hak nya yaitu mendapatkan pendidikan. Hal ini dikarenakan peraturan dari pihak sekolah tidak sejalan dengan UU RI No. 35 tahun 2014.

\section{Saran}

Saran yang penulis berikan dalam hal perlindungan hukum terhadap pelajar yang melakukan penyalahgunakan obat jenis Psikotropika dalam proses penyidikan adalah sebagai berikut :

1. Perlindungan hukum terhadap Pelajar yang melakukan penyalahgunaan obat jenis Psikotropika seharusnya lebih maksimal, tetapi dalam pembahasan kali ini ada hak-hak anak yang belum diberikan sebagaimana disebutkan dalam UU RI No. 35 Tahun 2014 Tentang Perubahan Atas UU RI No. 23 Tahun 2002 Tentang Perlindungan Anak. Seharusnya pelajar yang melakukan penyalahgunaan obat jenis Psikotropika setelah melakukan proses dikepolisian dengan hasil diversi dan retrorativejustice, supaya diperbolehkan menjalani proses belajar mengajar kembali di sekolahnya, bukannya malah dikeluarkan dari sekolah yang ahirnya anak tersebut tidak mendapatkan pendidikan seperti seharusnya.

2. Agar Pemerintah lebih memperhatikan perlindungan hukum terhadap pelajar yang melakukan tindak pidana penyalahgunaan obat jenis psikotropika atau tindak pidana yang lainnya, terutama bagian Pengawasan di tingkat Kabupaten, yaitu Dinas Pendidikan, supaya dari pihak sekolah tidak seenaknya sendiri mengeluarkan anak dari sekolah dengan alasan adanya aturan dari sekolah itu sendiri serta mencemarkan nama baik sekolah. 
3. Agar Pemerintah segera mengeluarkan aturan yang pasti untuk semua sekolah di Purbalingga, bagaimanakah perlakuan pihak sekolah yang seharusnya terhadap semua siswanya dalam hal belajar mengajar ataupun dalam memenuhi hak-haknya sebagai anak yang sedang menjalani proses belajar mengajar di sekolah, serta mensejalankan aturan sekolah dengan UU RI No. 35 Tahun 2014 Tentang Perubahan Atas UU RI No. 23 Tahun $2002 \quad$ Tentang Perlindungan Anak. Sehingga hak-hak anak dapat terpenuhi dengan maksimal

\section{DAFTAR PUSTAKA}

Dewata, Mukti FN, Dkk. 2010. Dualisme Penelitian Hukum Normatif dan Empiris. Pustaka Pelajar, Yogyakarta.

Gosita, Arif. 1985. Masalah Perlindungan Anak, Jakarta: Akademika Pressindo.

Moeljatno. 2005. Asas-asas Hukum Pidana. Jakarta. Rineka Cipta.

Poernomo, Bambang. 1997. Asas-asas Hukum Pidana. Jakarta, Ghalia Indonesia.

Poerwadarminta, W.J.S. 1984. Kamus Umum Bahasa Indonesia. Balai Pustaka : Amirko.

Salam, Moch. Faisal. 2005. Hukum Acara peradilan Anak di Indonesia, Mandar Maju, Bandung.

Setiono. Rule of Law (Supremasi Hukum). Surakarta. Magister IImu Hukum.
Soekanto, Soerjono, dkk. 2007. Penelitian Hukum Normatif Suatu Tinjauan Singkat. PT. Raja Grafindo Persada , Jakarta. 2010. Pengantar Penelitian Hukum. Ul-Press, Jakarta.

Soekirno. 1993. Kamus Besar Bahasa Indonesia. Balai Pustaka.

Sugiyono. 2008. Memahami Penelitian Kualitatif. Alfabeta, Bandung

Undang-undang RI No. 35 tahun 2014 Tentang Perubahan Atas UU RI No. 23 tahun 2002 Tentang Perlindungan Anak.

Undang-Undang No. 3 Tahun 1997 Tentang Pengadilan Anak.

RancanganKitab Undang-undang Hukum Pidana (KUHP), Direktorat Jenderal

Peraturan Perundangundangan Departemen Hukum dan HA M, Jakarta. 